Volume 6, Issue 2, 145 - 156.

ISSN: $2165-8714$

http://www.eu-jer.com/

\title{
Examining the Reading Habits, Interests, Tendencies of the Students Studying at the Faculty of Education and Analyzing the Underlying Reason behind Their Preferences
}

\author{
Omer Faruk Tavsanli * \\ Uludag University, TURKEY
}

Abdullah Kaldirim

Dumlupinar University, TURKEY

Received: February 27, 2017 - Revised: March 8, 2017 • Accepted: March 24, 2017

\begin{abstract}
Acquiring the reading skills and using this skill effectively throughout life is possible by a qualified education hence qualified teachers. Therefore; teachers and candidate teachers are suggested to be; acquired the reading skills, focused on information and learning, trained well as individuals having knowledge of their fields and pedagogics. By the context; the aim of the study is suggested as examining the reading habits, interests, tendencies of the students studying at the Faculty of Education and analyzing the underlying reason behind their preferences. The descriptive phenomenology method; one of the qualitative research methods is used in the study. The studying group within the research is occurred by the 10 students from 5 different fields of Education Faculty, who read books constantly. The data acquired is collected by semi-structured interview questions and content analysis method is benefited to analyze the data. According to the results of the study; 140 discourses are observed to be expressed within the 6 themes, due to the reading habits, interests and tendencies of the students studying at the Faculty of Education. The mentioned themes herein, are formed as the following: "book type interested", "content interested", "topic interested", "acquiring the reading habits", "criteria for preferring books", "the effect of social environment to prefer books". While the most expressed theme is revealed as "criteria for preferring books", the least one is about the reading habits, within the research.
\end{abstract}

Keywords: Reading habits, reading interests, reading tendencies, pre-service teachers, reasons.

To cite this article: Tavsanli, O. F., \& Kaldirim, A. (2017). Examining the reading habits, interests, tendencies of the students studying at the faculty of education and analyzing the underlying reason behind their preferences. European Journal of Educational Research, 6(2), 145-156. doi: 10.12973/eu-jer.6.2.145

\section{Introduction}

The individuals realize most of their learnings and acquire many things by listening, up to the beginning of academic life. Speaking skill also emerges as a talent acquired, as from the first years of one's life. Listening and speaking are to be improved with writing and reading skills from the beginning of academic life, in the framework of native tongue's education. The main targets of improving the speaking skills mentioned for the students are expressing themselves by the language, apperceiving the various forms of expressions, enriching their thoughts and dream world via various information sources (MEB, 2006: 2). Speaking skill is gaining importance on account of facilitating to expand the individual's minds, to edit information, to use the language, to develope mental abilities and knowledge enrichment, through the target (Gunes, 2007).

Reading is the first step of learning and academic success (Anderson, Hiebert, Scott and Wilkinson, 1985). The academic success of the student is related with reading for understanding. Palani (2012) states that effective reading is on the way to effective learning hence it is completely related with eduactional process, therefore; educational success is directly about reading habits. According to Slavin, Cheung, Groff and Lake (2014) the students, whose reading success are in low level, have difficulty to understand the complex texts within their academic lives, so that; they hardly recognize the concepts relating the courses and the mentioned students are supposed to be in trouble about school and business. Also Alvermann (2005) points out that the students who have difficulties in reading but passing their classes can not get the necessary pre-information during the following steps, therefore; they cannot understand the text included in curriculum. The results of the researches held support the expressions above. Reed, Petscher and Truckenmiller (2016) state that reading skills have great importance about the concepts both to learn and to explain for the natural sciences course within their relational scanning research. Fisher, Frey and Nelson (2012) implemented their program in 44 schools settled in a county from very low socio-economic level in order to support students to

\footnotetext{
* Corresponding author:

Omer Faruk Tavsanli, Uludag University, Bursa, Turkey

Email: omerfaruktavsanli@gmail.com
} 
understand they read, hence; the authors achieved their goal by arising the students' low level academic success over their expectations. Based on the results mentioned; the reading skills are supposed to affect the individuals' academic level.

Considering the reading activities as fundamental educational services; reading is suggested to contribute both individual and social life. The reason herein is; occurring the economic, social and cultural capital together with its improving. According to McMahon (2000); it is possible to invent new technologies or using them more efficiently for individuals, arising of welfare also contributing democracy's development and decreasing the crime rates for society, by benefiting qualified educational activities. In the opposite situation; unemployment, unwanted employing conditions, low fees and rights losses, therefore; deprivation and poverty occurs (Yildiz, 2008). Barton and Jenkins (1995), by supporting the ideas mentioned; discourses about a strong relationship between poverty and low level reader. Besides; Palaz, Senergin and Oksuzler (2013) points at the negative effect of the differences between educational levels in Turkey, on the country's income distribution. In the context; reading skill is supposed to be a major factor affecting developing and improvement for both individuals, society and country. Considering its contribution for individuals, social and academic life; the importance of reading skill is revealed. Therefore; reading skill is suggested to be acquired and improved by each individual.

According to the statistics for 2015 (TUIK, 2017), Turkish National Education System can be determined as successful due to their contribution for reading and writing courses, by considering $96 \%$ of the individuals having reading and writing skills (literacy) in Turkey. However; coming on a decision simply over the mentioned rates may mislead the researchers, citizens and politicians having opportunity to innovate the education system. So; the researches relating the reading culture in Turkey are to be studied.

Due to “Turkey Reading Culture Map" prepared by Republic of Turkey, Ministry of Culture (Ministry of Culture, 2011); it is observed that $31,32 \%$ of society does not read any book besides the rest of the Turkish people read irregularly and they rarely choose a book. According to R\&D report by "Research Center for Democracy and Education"; only 6 hours is spent annually to read and reading ratio is evaluated as 0,01\% in Turkey. Therefore; though 96\% of the population have reading and writing skills (literacy), it is observed that this qualification could not acquire literacy style for the entire country.

As a result of the developments and improvements in the last century worldwide; the societies are to be defined and reformed themselves for any field. Concerning the mentioned status; it is revealed that the Turkish society -of which majority still does not have a literacy style, does not have reading habits, does not have a proper reading cultureimmediately needs to study their (un)reading matter. Reading is the key for gaining, reforming, producing and distributing information. Unreading societies can not produce so that they can not earn. Therefore; societies having (un)reading matters are not supposed to conceive the developments today and they are not able to stand in the 21st century. Thus; reading activities should be transformed into habits for the individuals to be refreshed and developed themselves (Ungan, 2008). According to Sever (2011); "acquiring the habit of reading" must be one of the targets of reading education.

Yildiz (2010) defines reading habit as "spending time properly and constantly for learning, having fun and relaxing thorough individuals' interest, wonder and needs" and states that many variables such as personal characters, interests, wonders, needs, targets, environment and national policies may be effective to acquire the habit. Herein; the variable of "individuals' reading interests" is determined to be the most important one because individuals "having really need to read" and "reading an attracting book eagerly" can transform their reading activities into habits (Sunbul and the others, 2010: 13). Therefore; text selections in the context of reading education activities must be based on the interests of students (Palincsar and Duke, 2004). Individuals' reading tendencies is another variable which is affecting to acquire reading habits. It is evaluated as a concept which differentiates due to target, wonder, need and age of individuals. So that; determining the individuals' reading tendencies is important to acquire reading habit and improving the reading skills (Tosunoglu, 2002: 549).

Acquiring the reading skills and lifelong benefiting is probable by well-equipped teachers trained by a qualified education (Arici, 2015). Therefore; teachers and candidate teachers are suggested to be trained as individuals; acquired reading habits, focused on information and learning also having sufficient information about their fields and pedagogy. There are various researches held in Turkey relating with the level of teachers' reading habits who are role models for the students through their process of acquiring literacy (Ari \& Demir, 2013; Aslanturk \& Saracaloglu, 2010; Elkatmis, 2015; Bozkurt \& Serin, 2003; Arici, 2008; Gur, 2014). Considering the results so far; the level of candidate teachers' reading habits and their reading interests are suggested to be insufficient. By the context; the aim of the study is determined as analyzing the reading habits, interests and tendencies with underlying factors for the students having their education in undergraduate level at Faculty of Education. So that; it is possible to find out the responds of the inquiries about acquiring reading habits, tendencies of the students, factors determining their interests and preferences, via the students having literacy style. Developing policies through acquiring reading habits for the students is suggested to be quite important based on the results and responds mentioned above. 


\section{Methodology}

\section{Model of the Study}

The descriptive phenomenology method; one of the qualitative research methods is used in the study. The mentioned method interested in the question of "what is known by individuals in reality" has an epistemological view (Ersoy, 2016). Through the descriptive phenomenology studies in general; it is aimed to analyze and describe the perceptions of individuals occurred by their experiences about a phenomenon, concept or situation (Reiners, 2012).

During the phenomenologic studies; "perceiving the topics, situations or concepts of the people or groups having experience about the subject" is studied besides it is tried to be understood how interior and external relations about the concept are formed by the mentioned people (Christensen, Johnson and Turner, 2015; Cepni, 2012). Phenomenology method facilitates us to analyze the phenomenons being not well-known and undefined though they are being noticed by us (Creswell, 2012; Yildirim and Simsek, 2011). It is not aimed to reveal definite and generalized results from phenomenologic studies, like all of the other qualitative research methods. Nevertheless; phenomenology method provides us to recognize the concept researched, far better. Having conclusion about the phenomenon, by analyzing very well in a multidimensional way, is suggested to have great contribution on both scientific field and practises (Sart, 2015; Yildirim and Simsek, 2011). The phenomenon studied and analyzed within the study is reading habits, interests, tendencies and the underlying psychological perceptions of the students attending Faculty of Education.

\section{Studying Group}

It is important to gather individuals, who are having experiences about the topic and utilized, for the study while determining studying groups for phenomenological studies (Creswell, 2012; Yildirim and Simsek, 2011). The studying group within the research is occurred by the 10 students from 5 different fields of Education Faculty, who read books constantly. Criterion sampling, one of the purposive sampling methods, is used to form the studying group. This method is based on the principle of including the individuals within the study who are suitable for the criteria determined before (Christensen, Johnson and Turner, 2015). Reading constantly and participating volunteerly are determined as the criteria for our study additionally participants included in the study are interviewed. The participants stated before the study that they read books constantly and they can participate in the study as volunteers by the interviews. The reading habits and departments of the students included in the studying group are illustrated below in Table 1:

Table 1. Reading Habits of Participants

\begin{tabular}{cccc}
\hline Participants & $\begin{array}{c}\text { How Many Minutes } \\
\text { Spent At Least, When } \\
\text { you Begin Reading? }\end{array}$ & $\begin{array}{c}\text { How Many Books } \\
\text { Read In a Week? }\end{array}$ & $\begin{array}{c}\text { Departments of Students } \\
\text { (within } \\
\text { Faculty of Education) }\end{array}$ \\
\hline A & 30 & 1 & Mathematics \\
B & 120 & 1 & Preschool Education \\
C & 60 & 2 & Natural Sciences \\
D & 90 & 1 & Social Sciences \\
E & 90 & 1 & Preschool Education \\
F & 60 & 1 & Primary Education \\
G & 30 & 1 & Mathematics \\
H & 30 & 1 & Social Sciences \\
I & 180 & 2 & Primary Education \\
J & 45 & 1 & Natural Sciences \\
\hline
\end{tabular}

\section{Data Collecting Tools}

Interview is the basic data collection tool for the phenomenological researches (Yildirim and Simsek, 2011). Two interviews have been conducted with the students for the study. In the first one; it is aimed to reveal the reading habits, interests and tendencies of the students. The second interview is used to find out the psychological reasons underlying the reading habits, interests and tendencies of the students by benefiting the analysis results of the first interview. The data acquired is collected by semi-structured interview questions. During the preparation of the interview questions; the principles such as being apparent, adjustable and not directing to any answer are minded carefully. After forming the interview questions sheet; it is asked to 3 experts from Department of Turkish Language Education for their approval. Hence; a pilot study is conducted with 20 students to test the questions. Several changes are assumed about the order of questions after the pilot study due to experts' opinions and implemented besides some additions are made to semi-structured interview questions sheet. Consequently; semi-structured interview sheet is decided to be occurred by 14 questions. The interviews are conducted concerning the time of courses due to researcher and students. The conversations accomplished are recorded with the participant's approval. The recording during semi-structured 
interviews lasted for 126 minutes in total. Furthermore; these records have been resolved so that data of 48 pages are acquired. While recording the data; all the expressions used by students and researcher are written immediately just as they are, and great attention has been paid to ensure accuracy meticulously. The voice records acquired by the conversations are also listened by 2 other experts to ensure the reliability of the data, therefore; it is compared by the researcher's records. Few missing parts are noticed by the comparision and they are added soon.

\section{Analysis of Data}

The content analysis method is benefited in the study to analyze the data. Content analysis is one of the methods to determine the presence of words, concepts and characters within the study and to reveal their underlying relations (Merriam, 1998; Kiziltepe, 2015). The content analysis method is also used to analyze the content of written documents since it is benefited to reveal the data collected from various tools (Cavanagh, 1997).

After the interviews are conducted, data acquired by voice records are transformed into written documents for the research. Furthermore; all the interviews are examined and proper codes are formed for the discourses. The codes are grouped under similar titles and themes attained; so that codes are matched to themes. The same process is done by another researcher and the researchers have come to an agreement for the codes and themes which are being detected unlike the others. The codes and themes acquired are illustrated in Findings Section together with tables and figures. Additionally the codes and themes are suppported by mentioning the discourses of students' interviews. Consequently; reading habits, interests and tendencies of the students from Faculty of Education are revealed and their underlying psychological factors are examined.

Data analysis is held in 2 steps within the study. By the first one; the interviews are analyzed and concluded. Furthermore; the underlying facts of the results acquired through the analyses of interviews are revealed.

\section{Findings / Results}

The content analysis method is benefited in the study to analyze the data. Content analysis is one of the methods to determine the presence of words, concepts and characters within the study and to reveal their underlying relations (Merriam, 1998; Kiziltepe, 2015). The content analysis method is also used to analyze the content of written documents since it is benefited to reveal the data collected from various tools (Cavanagh, 1997).

After the interviews are conducted, data acquired by voice records are transformed into written documents for the research. Furthermore; all the interviews are examined and proper codes are formed for the discourses. The codes are grouped under similar titles and themes attained; so that codes are matched to themes. The same process is done by another researcher and the researchers have come to an agreement for the codes and themes which are being detected unlike the others. The codes and themes acquired are illustrated in Findings Section together with tables and figures. Additionally the codes and themes are suppported by mentioning the discourses of students' interviews. Consequently; reading habits, interests and tendencies of the students from Faculty of Education are revealed and their underlying psychological factors are examined.

Data analysis is held in 2 steps within the study. By the first one; the interviews are analyzed and concluded. Furthermore; the underlying facts of the results acquired through the analyses of interviews are revealed.

Table 2. The Book Types Students Have Interest in

\begin{tabular}{lc}
\hline Book Types Students Have Interest In & f \\
\hline Novels & 10 \\
Educational books & 3 \\
Poetry books & 2 \\
Psychological books & 1 \\
Historical books & 1 \\
\hline
\end{tabular}

As it is seen in Table 2; students state that they mostly have interest in novels, as the following:

A: "Novels are more pleasant, it makes me happy when i read novels. You can find many things in novels, from your life. Besides novels are more exciting."

E: "I mostly prefer reading novels because I feel myself in novels. Poets are fair, i understand it. But i do not feel them, poets are not attractive for me."

It is illustrated that students prefer educational books after novels. They explain it as follows:

D: "I read the books about teaching. Consequently; we will also become teachers and we need to improve ourselves." 
H: "I prefer the books including the context of education. We will become teachers and need to read books about it."

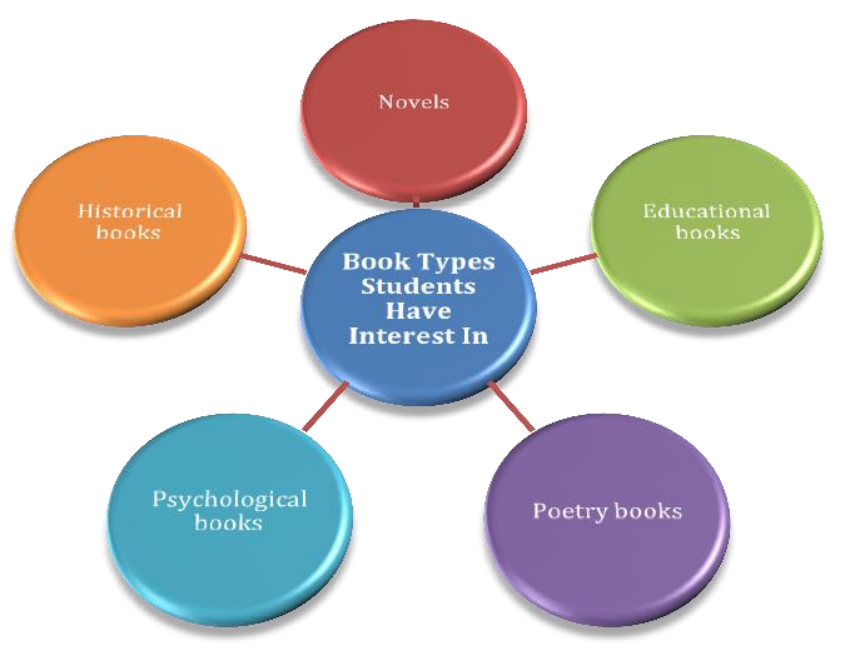

Figure 1. The Model Occurred Through the Book Types Interested in the Students Attending Faculty of Education

One of the themes acquired by the discourses of the students attending Faculty of Education is "the content of books interested in". 15 statements are acquired by students about the content of books. It is noticed that the discourses about this theme are being in diversity. "Tackling the challenges" is the most repeated theme definited by the discourses herein. Additionally; other themes are defined as the following and shown in Table 3: "children's suffering", "war", "melancholia", "love", "friendship", "sacrificing", "history", "women's rights" and "intrigue."

Table 3. The Content of Books Students Have Interest In

\begin{tabular}{lc}
\hline Content of Books Students Have Interest In & f \\
\hline Tackling the challenges & 5 \\
Children's suffering & 2 \\
War & 1 \\
Melancholia & 1 \\
Love & 1 \\
Friendship & 1 \\
Sacrificing & 1 \\
History & 1 \\
Women's rights & 1 \\
Intrigue & 1 \\
\hline
\end{tabular}

According to the table above; the most mentioned theme is determined as "tackling the challenges". The students state that tackling needs to be respected, they also meet difficulties through their lives and they are inspired by novels. The discourses are as follows:

G: "One's surviving despite of all problems is inspiring. As individuals; we also face many problems and we can resist by this kind of books."

H: "There is a teacher told in the story having troubles in the class. I read the novel because i put myself in his place and try to feel the situation. Because i also will be a teacher and have to find solutions for that kind of matters." 
The second "content theme" mentioned above by the students is "children's suffering". The discourses about the theme are determined to be expressed by women. They state that "children's suffering" theme is unbearable but each individual should be aware of the matter. The expressions about the theme are as the following:

B: "Children's suffering in the real life or novel, all the same. It is life and it hurts me so much. We have to notice them."

E: “Women's life in Afghanistan, before and after Taliban, is told in details by the novel. The women also kids about 10 years old can not go out without wearing burka. The progress is described in the novel and consequently i was crying at the end of the story."

The other theme, revealed by discourses of students, is "topic interested". The students express 23 discourses within the topic as 7 codes. The codes are as follows: "love, "science fiction", "drama", "real life story", "adventure", "humour" and "detective". The most talked topic by students herein is determined as "real life stories". Further; drama, adventure and detective sub-themes are mentioned as the other favorite topics. The least amount of discourses are expressed about the titles of love, science fiction and humour. The "topic interested" list acquired by students' discourses is shown in Table 4, additionally; the model occurred by their opinions is illustrated in Figure 2 below:

Table 4. The Topic of Books Students Have Interest In

\begin{tabular}{lc}
\hline Topic of Books Students Have Interest In & f \\
\hline Real life story & 8 \\
Drama & 4 \\
Adventure & 4 \\
Detective & 3 \\
Humour & 2 \\
Love & 1 \\
Science fiction & 1 \\
\hline
\end{tabular}

As it is seen in Table 4; students mostly have interest in topics within real life stories. Because it is said that they do not expect utopian events, face challenges through their lives, find similarities in the story from their experiences and are affected by real lives. Discourses about the topic are shown below:

C: "Real lives, their battles always affect us, not utopian."

G: "Because there is whole story of a young man, besides he/she is a student in university; like us, it is about our lives."

H: "I am not day dreamer; i want to see real things from my life."

After real life stories; mostly drama and adventure codes are mentioned. The discourses about drama topic are expressed by women and it is observed that they are more affected by the stories. The students state that they prefer adventure since it is more funny and live, as they are shown:

B: "I suppose that i prefer sad stories because emotional things affect me."

E: “Drama have great effect on me. Women's life in Afghanistan, before and after Taliban, is told here. The women also kids about 10 years old can not go out without wearing burka in their era, $\mathrm{i}$ was crying at the end of the story."

I: "I enjoy adventure in novels, i feel closer. Maybe it is far away from me and i try to be there, in its place.

Few amounts of preferences are about the topics as; detective, humour, love and science fiction. Students preferring humour books state that they need laughing so that they read comics, as the following:

E: "I like it, humourous. I generally prefer humour books. Life is really stressful nowadays, isn't it?" 


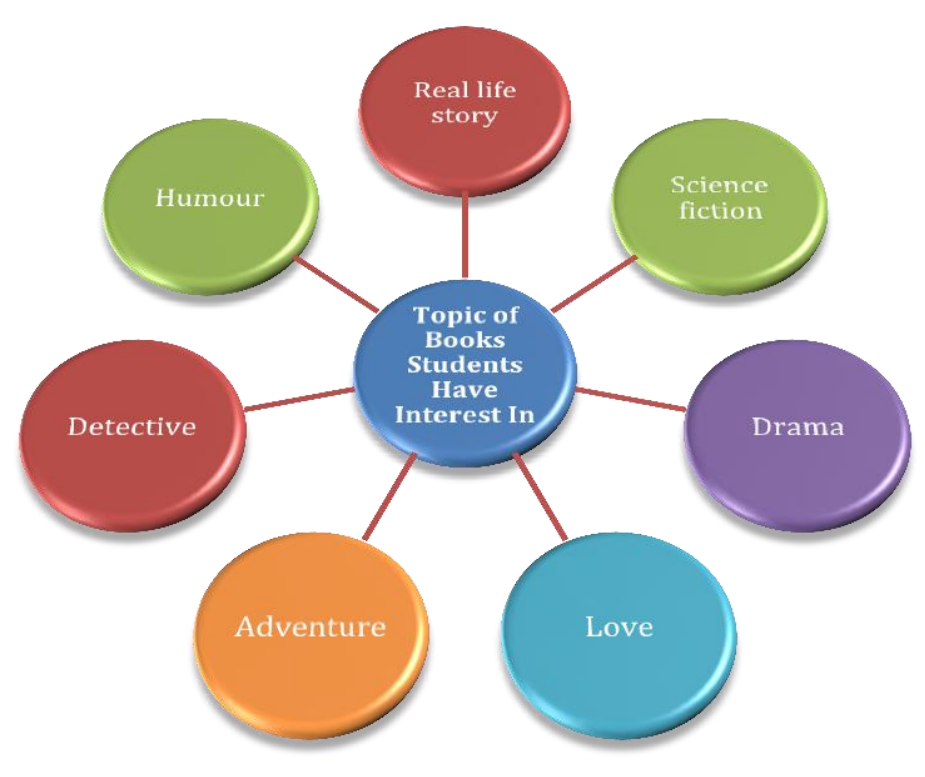

Figure 2. The model occurred due to Topic of Books Students Have Interest In

11 discourses are stated by students about the theme of "acquiring the reading habits". Students state their opinions about how they acquire book reading habits including the reasons, within the theme. Findings obtained herein is supposed to be used by instructors through their targets. The codes mentioned by students about acquiring reading habits are illustrated below in Table 5.

Table 5. Acquiring book reading habits for students

\begin{tabular}{lc}
\hline Acquiring book reading habits for students & f \\
Support of teacher & 4 \\
Meeting a book enjoyed & 2 \\
Gift & 1 \\
Need & 1 \\
Improving himsef/herself & 1 \\
Reading short books & 1 \\
Finding something about himsef/herself in the book & 1 \\
\hline
\end{tabular}

It is seen from the table above that; "support of teacher" is stated by majority of the students as the reason for their reading habits. So that; the importance of teachers' behaviours on students' lives is revealed. For example:

B: "I used to be an unreading person actually. My Turkish teacher in 7th grade has shared many things with me then and encouraged me so. Furthermore; i became a book reader, especially in high school i acquired reading habit."

G: "In secondary school; I used to read excessive amount of books especially in 7th and 8th grades. Furthermore; our teachers in high school also encouraged us to read. My teachers always had effect on my reading habit."

Acquiring reading habit is determined to be mostly affected by teacher's support. Besides; other factors are existed, being diversified due to personal conditions. such as meeting a book enjoyed, gift, need etc.

E: "I did not read actually, up to 15 years old. My friend was reading constantly then, and i affected from him/her. He/she was reading the books of famous author Ipek Ongun. I did read her series and had fun. After that $\mathrm{i}$ tried the other books and authors; i still have been reading."

$\mathrm{H}$ : "I did have trouble in talking. My elder brother is primary school teacher. He advised me to read books to solve the problem. Then i got reading habit.

D: "I was enrolled in Social Sciences Department of our high school. Then i thought that i need reading to improve myself. Hence, i often tried to read books." 
The most amount of discourses expressed by students is realized seeing the theme of "criteria for reading books". 55 discourses are acquired within book preferring, including various codes such as "topic", "content", "cover", "being exciting", "author", "friend's recommendation" and etc. As they are shown below:

Table 6. The criteria for reading books

\begin{tabular}{lc}
\hline Criteria for reading books & f \\
\hline Being exciting & 10 \\
Content & 8 \\
Topic & 7 \\
Friend's recommendation & 5 \\
Cover & 5 \\
Author & 5 \\
Title & 2 \\
Language & 2 \\
Persuasiveness & 2 \\
Book reading ratios in the world & 2 \\
Price & 1 \\
Book review magazines & 1 \\
Cultural suitability & 1 \\
Advertisement & 1 \\
Texture & 1 \\
Being surprising & 1 \\
Introduction letter & 1 \\
Publisher & 1 \\
& 1 \\
\hline
\end{tabular}

According to the table above; the students remark that the books must be exciting. Because reading exciting books is defined by them as joyful, lively and attractive, like it is seen below.

B: "Being exciting is very important for me. When i begin to read; the first 30 pages should catch me otherwise i don't go on. If i read a book, number of pages doesn't matter, it is over in 2 days."

D: "Ending of an exciting book makes me sad. I want to live it within the story. I read attractive and exciting books very quickly."

E: "The book catchs the reader as long as its process is well arranged. You feel as if you are in Afghanistan in her body."

Content and topic are the other favorite codes mentioned above. While preferring a book, students pay attention for the topic and content, as follows.

I: "There is a lady in the story, she was marrying a man she unwanted. Her husband becomes ill and she looks after him. I care about the topic so much for reading."

D: "I look at the shelves and pick the first one i stare at, then i read the content from back cover. If it is attractive for me, i buy it."

A: "I generally choose them due to their topics. The topic is very important for me."

Recommendation, cover and author are the other favorite codes mentioned within the study, as the following:

J: "The author is very important, firstly. But i also can read an author i never met, no need to be prejudiced."

I: "Whenever my friends recommend me a book, i read it. I mean; they affect me."

B: "I care about the cover, it affects me also i exactly read the back cover. I look for them in book fairs."

The last theme formed by discourses of the students is "the effect of social environment to prefer books". 19 discourses are expressed within the theme herein, under 3 codes as family, friend and teacher; as they are shown in Table 7. 
Table 7. The effect of social environment to prefer books

\begin{tabular}{lc}
\hline Effect of social environment to prefer books & f \\
Friend & 10 \\
Teacher & 5 \\
Family & 4 \\
\hline
\end{tabular}

The table above based on the "effect of social environment to prefer books" illustrate that mostly friends further teachers and families have effect on the students. Teachers are observed to be effective also about acquiring reading habits, before. The discourses mentioned are as follows:

B: "Before buying the book; i ask about it to my friends who read recently. They have effect on me. If i had read a book earlier, i do the same and tell my opinions."

E: "My room mate recommends me about a book now, when i was younger in high school; teachers used to do the same thing. I feel i am affected by their opinions as if i obey their principles and care them."

C: "My brother reads a lot, he often tells me about it and he may recommends me. Whenever i am recommended about a book, i read it."

Figure 3 is occurred by the opinions illustrated in Table 7:

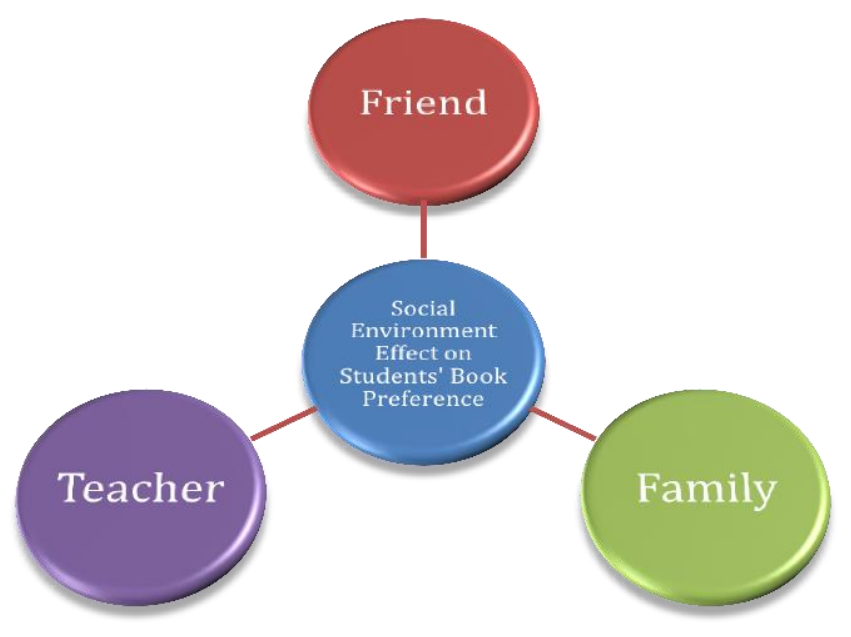

Figure 3. The model occurred due to the opinions students about social environment effect on students' book preferences

\section{Discussion and Conclusion}

The study is based on the interview conducted with students reading constantly from Faculty of Education who are supposed to be teachers in the near future. Samuels and Farstrup (2011) state that qualified education worldwide is solely possible by training teachers as "sufficient professionals" and "good readers". By the context; determining the book reading interest and tendencies of candidate teachers through education policies are considered as a prerequisite in order to reach reading standards (Srommen and Mates, 2004). Additionally; the book reading rate is evaluated to be low in Turkey, due to the studies held recently (Arici, 2015; Kus and Turkyilmaz, 2010; Cocuk Vakfi, 2006). The situation reveals the importance of the research to determine reading interest and tendencies of candidate teachers through the studies to acquire reading habits for students from each grade.

According to the findings of the study; the most interested book type by the students from Faculty of Education is detected to be novels. Students state that novels are more exciting, joyful and relaxing besides they feel themselves in the story. Additionally; the students within the research are observed to preferred educational books in order to improve themselves through their teaching profession. Novels and educational books are determined to be preferred by students from each department. Also; poetry books are read by mostly women and students from Preschool Education Department. According to the study by Kus and Turkyilmaz (2010); students from Faculty of Education are determined to be reading novels and newspapers, in common. Similarly, Sahiner (2005) finds out that secondary school teachers mostly prefer reading novels, newspapers and magazines, by his/her research. According to Ayyildiz (2006); students usually read novels and tales. Regarding the results in general; novels are observed to be the most preferred book type, by both students and candidate teachers. Besides newspapers and magazines are also detected to be the 
often read tools. Though candidate teachers are observed to read educational books due to the study held; Kus and Turkyilmaz (2010) find out that reading rates of educational books and article for the students from the departments of Turkish Language and Social Sciences is very low. By the context; candidate teachers are to be encouraged to read educational books and articles to follow the developments within their fields, to improve and to train themselves as a teacher.

One of the other results of the research is detected as; students prefer to read the books about tackling the challenges and children's rights. It is concluded herein that; tackling is perceived as a respectful behaviour by the students. The books relating children's rights are read by women. The students state that they are very sorry about children's victimization and try to learn about the issue. Several differences are also observed due to the gender of students; by the other studies through the reading habits and tendencies of students. Gomleksiz (2004) and Korkmaz (2007) detect that various differences are existed by the gender of students such as reading habits, reading periods and preferences.

Another result acquired from the discourses of students is they prefer real life stories, drama, adventure and detective books to read. Real life stories are searched due to the fact that the students do not expect utopian events and they suggest to face merely realities. Therefore fiction style books are exactly not favorite for them. Drama books are searched by just women and they state that drama style affects them much more than the others. Male students are determined to prefer mostly detective and adventure books. So that the results mentioned above are similar with the other findings acquired by the other studies based on the relation between gender and book preference (Gomleksiz, 2004; Korkmaz, 2007).

Acquiring book reading habits of students is revealed to be realized by mostly teachers' support. Hill and Beers (1993) find out that the most effective factor for students to acquire reading habit and to read books constantly is family and teachers. Therefore; students from Faculty of Education are to be models for their future students, as teachers and readers, during their professions (Benvides, 2006).

Another result of the study is; the students enjoy reading exciting books due to funny contents and pattern of events. Additionally; students state that they prefer books according to their contents, authors, topics and covers. They are determined to read books due to several qualifications, not randomly, so that; the students herein are defined as conscious readers. According to Barry (2002); preferring the books due to several qualifications and determining individual criteria reveal that they, as readers, have book reading consciousness. One of the results acquired from this research is that; "social environment" is being a factor to affect students' book preferences. "Friend" is revealed to be the most effective factor for students in their social environment to affect reading habits. Further; teachers and families from their social environment are determined as the effective factors for the students. Studies held point out that families have a serious effect on reading habits for students (Ehri and Roberts, 2006; Saracho, 1997).

There are several suggestions offered within the study for the researchers, families, teachers and also officers who lead education policies. Literacy education in the family is considered to be very important because reading firstly begins at family and family members are the initial samples for kids.

As a sample in Netherlands; Ministry of Education sends a box to each kid being in 3 years old, within the Dutch Education System. Several brochures are included in the box to develop literacy consciousness for family additionally brochures about the books to read and activities to improve literacy skills for students. Various activities are offered to the families, to improve literacy skills of the children, through the aim of occurring social consciousness about literacy education in common (Erginer, 2012). Thus; the officers who are organizing educational policies have responsibilities about implementing these activities. Furthermore, it is substantial for the teachers to improve themselves as a qualified reader, therefore; students from Faculty of Education must read constantly. In this context; students are to be encouraged by the research and studies via academics and faculties who train candidate teachers.

\section{References}

Alvermann, D. E. (2005). Literacy on the edge: How close are we to closing the literacy achievement gap? Voices from the Middle, 13(1), 8-14.

Anderson, R. C., Hiebert, E. H., Scoth, J. A., \& Wilkinson, I. A. (1985). Becoming a nation of readers: The report of the commission on reading. Washington: U.S. Department of Education.

Ari, E., \& Demir, M. K. (2013). Ilkogretim bolumu ogretmen adaylarinin kitap okuma aliskanliklarinin degerlendirilmesi. [Assessing reading habits of student teachers' at department of elementary education]. Ana Dili Egitimi Dergisi, 1(1), 116-128.

Arici, A. F. (2015). What Turkish Teachers/Preservice Teachers Should Read? - A Suggested Book List. Hacettepe Universitesi Egitim Fakultesi Dergisi-Hacettepe University Journal of Education, 30(3), 1-15.

Arici, A. F. (2008). Okumayi niye sevmiyoruz? Universite ogrencileri ile mulakatlar. [Why don't we lıke readıng? Interviews with undergraduates] Mustafa Kemal Universitesi Sosyal Bilimler Enstitusu Dergisi, 5(10), 91-100. 
Aslanturk, E., \& Saracaloglu, A. S. (2010). Sinif ogretmenlerinin ve sinif ogretmeni adaylarinin okuma ilgi ve aliskanliklarinin karsilastirilmasi. [Comparison of the classroom teachers and the candidate classroom teachers' reading interests and reading habits]. Anadolu Universitesi Sosyal Bilimler Dergisi, 11(1), 155-176.

Barton, P. E., \& Jenkins, L. (1995). Literacy and dependency: The literacy skills of welfare recipients in the united states. Princeton: Educational Testing Service.

Benvides, Tina De L. (2006). Personal reading habits and literacy instruction in preservice teacher. (Unpublished master thesis). Nipissing Universty Faculty of Education, Ontario.

Barry, Arlene L. (2002). Reading strategies teachers say they use. Journal of Adolescent \& Adult Literacy. 46 (2), 132141.

Bozkurt, N., \& Serin, O. (2003). Universite ogrencilerinin okuma ilgileri ve okuma aliskanliklarini etkileyen faktorler [Factors affecting reading attitudes and reading habits of university students]. Eurasian Journal of Educational Research, 4(12), 149-157.,

Cavanagh, S. (1997). “Content Analysis: Concept, Methods and Applications”, Nurse Researcher, 4(3), s. 45-59.

Christensen, L. B., Johnson, R. B., \& Turner, L. A. (2015). Arastirma Yontemleri: Desen ve Analiz. [Research methods design and analysis]. (Cev. Ed: Ahmet Aypay), Ankara: Ani Yayincilik.

Creswell, J. W. (2012). Educational Research, Boston: Pearson.

Cepni, S. (2012). Arastirma ve Proje Calismalarina Giris, [Introduction to research and project work], Trabzon: Celepler Matbaacilik.

Cocuk Vakfi. (2006). Turkiye'nin okuma aliskanligi karnesi[Reading habits of Turkey]. Istanbul: Cocuk Vakfi Yayinlari.

Ehri, L. C., \& Roberts, T. (2006). The roots of learning to read and write: Acquisition of letters and phonemic awareness. In D. K. Dickinson \& S. B. Neuman (Eds.), Handbook of early literacy research (Vol. 2, pp. 113-131). New York: Guilford Press.

Elkatmis, M. (2015). Sinif ogretmeni adaylarinin okuma ilgi ve aliskanliklari. [Reading interest and habits of classroom teachers]. Kastamonu Universitesi Kastamonu Egitim Dergisi, 23(3), 1223-1240.

Erginer, A. (2012). Avrupa Birligi Egitim Sistemleri. Ankara: Pegem Akademi Yayincilik.

Ersoy, A. F. (2016). Fenomenoloji. Ahmet Saban ve Ali Ersoy (Ed.), Egitimde Nitel Arastirma Desenleri, Ankara: Ani Yayincilik.

Fisher, D., Frey, N., \& Nelson, J. (2012). Literecy achievement through sustained professional development. Reading Teacher, 65(8), 551-563. doi:10.1002/TRTR.01082

Hill, Margaret H. ve Beers, G. Kylene. (1993). Teacher as readers: Survey of teacher personal reading habits and literacy activities in the classroom. Annual Meeting of National Reading Conference.

Gomleksiz, M. N. (2004). Gelecegin ogretmenlerinin kitap okumaya iliskin goruslerinin degerlendirilmesi. [Assessing the affectionate views of future teachers to read books]. (Firat Universitesi Egitim Fakultesi Ornegi). Yuzuncu Yil Universitesi, Elektronik Egitim Fakultesi Dergisi. Cilt:1, Sayi:1.

Gunes, F. (2007). Turkce Ogretimi ve Zihinsel Yapilandirma. Ankara: Nobel.

Gur, T. (2014). Ogretmen adaylarinin okuma ve bos zaman degerlendirme aliskanliklari. [Reading and leisure times activity habits of preservice teachers]. Zeitschrift fur die Welt der Turken, 6(1), 161-180.

Kiziltepe, Z. (2015). Icerik Analizi. Nitel Arastirma Yontem, Teknik, Analiz ve Yaklasimlar. (Ed: Fatma Nevra Seggie ve Yasemin Bayyurt), Ankara: Ani Yayincilik.

Korkmaz, I. (2007). Universite birinci sinifta okuyan ogrencilerin lise doneminde kitap okuma durumlarinin incelenmesi. [Investigation of the reading status of the students reading in university high school during the high school period]. Eurasian Journal of Educational Research. 27, 127-138.

Kus, Z., \& Turkyilmaz, M. (2010). Sosyal bilgiler ve Turkce ogretmeni adaylarinin okuma durumlari: (Ilgi, aliskanlik ve okuma stratejilerini kullanim duzeyleri. [Social studies and reading positions of Turkce teacher candidates: (levels of use of intelligence, habits and reading strategies]. Turk Kutuphaneciligi, 24(1), 11-32.

McMahon, W. W. (2000). Externalities, non-market effects, and trends in returns to educational invesments. OECD icinde, The appraisal of ivesments in educational facilities (s. 51-71). Paris: OECD Publications Service.

MEB. (2006). Ilkogretim Turkce dersi (6-8. siniflar) ogretim programi[Turkish lesson primary school (grades 6-8) curriculum. Ankara: Milli Egitim Bakanligi Talim Terbiye Kurulu Baskanligi. 
Merriam, S. (1998). Qualitative Research and Case Study Applications in Education. San Francisco: Jossey- Bass.

Palani, K. K. (2012). Promising Reading Habits and Creating Literate Social. International Reference Research Journal, 3(2), 1.

Palaz, S., Senergin, O., \& Oksuzler, O. (2013). Egitim duzeyi farkliliklarinin gelir dagilimina etkisi: Turkiye ornegi. [The effect of differences in educatıonal level on income distrıbutıon: the case of turkey]. Girisimcilik ve Kalkinma Dergisi, 8(2), 119-131.

Reed, D. K., Petscher, Y., \& Truckenmiller, A. J. (2016). The contribution of general reading ability to science achievement. Reading Research Quarterly, 1-14. doi:10.1002/rrq.158

Reiners, G. M. (2012). “Understanding the differences between husserl's (descriptive) and Heidegger's (Interpretive) phenomenological research", Journal of Nursing \& Care, 1 (119).

Samuels, S. J., \& Farstrup, A. E. (2011). What research has to say about reading instruction (4th ed.). Newark, DE: International Reading Association.

Saracho, O. N. (1997). Using the home environment to support emergent literacy. Early Child Development and Care, 201-216.

Sart, G. (2015). Fenomenoloji ve Yorumlayici Fenomenolojik Analiz [Phenomenology and interpretation phenomenological analysis]. Nitel arastirma yontem, teknik, analiz ve yaklasimlar [Qualitative research method, technique, analysis and approaches] . (Ed: Fatma Nevra Seggie ve Yasemin Bayyurt), Ankara: Ani Yayincilik.

Slavin, R. E., Cheung, A., Groff, C., \& Lake, C. (2008). Effective reading programs for middle and high schools: A bestevidence synthesis. Reading Research Quarterly, 43(3), 290-322. doi:dx.doi.org/10.1598/RRQ.43.3.4

Srommen, L. T., \& Mates, F. M. (2004). Learning to love reading: Interviews with olders children and teens. Journal of Adolescent ve Adult Literacy, 48, 188-200.

TUIK. (2017, 1 17). Turkiye IstatistiK Kurumu. Turkiye Istatistik Kurumu okuryazarliga gore nufus verileri [Turkey Statistics Institution population by literacy]: http://www.tuik.gov.tr/PreTablo.do?alt_id=1068 adresinden alindi

Turkiye Cumhuriyeti Kultur Bakanligi. (2011). Turkiye okuma kulturu haritasi [Turkey reading culture map]. Ankara: Turkiye Cumhuriyeti Kultur Bakanligi. http://www.kygm.gov.tr/Eklenti/55,yonetici-ozetipdf.pdf?0 adresinden alindi

Yildirim, A. ve Simsek, H. (2011). Sosyal bilimlerde nitel arastirma yöntemleri [Qualitative research methods in the social sciences], Ankara: Seckin Yayincilik.

Yildiz, N. (2008). Neoliberal kuresellesme ve egitim. [Neoliberal Globalization and Education]. D.U Ziya Gokalp Egitim Fakultesi Dergisi, 11, 13-32. 